\title{
Disruption of Fibroblast Growth Factor Receptor Signaling in Nonmyelinating Schwann Cells Causes Sensory Axonal Neuropathy and Impairment of Thermal Pain Sensitivity
}

\author{
Miki Furusho, ${ }^{1}$ Jeffrey L. Dupree, ${ }^{2}$ Melissa Bryant, ${ }^{1}$ and Rashmi Bansal ${ }^{1}$ \\ ${ }^{1}$ Department of Neuroscience, University of Connecticut Medical School, Farmington, Connecticut 06030-3401, and 2Department of Anatomy and \\ Neurobiology, Virginia Commonwealth University, Richmond, Virginia 23298-0709
}

\begin{abstract}
Axon-glial interactions are critical for normal functioning of peripheral nerves, and their disruption leads to peripheral neuropathies. Fibroblast growth factors (FGFs) are key players in peripheral nerve regeneration after injury. We investigated the role of FGF receptor (Fgfr) signaling in Schwann cells and the consequent regulation of normal Schwann cell-axon interactions. Fgfr1 and Fgfr2 were conditionally inactivated, either singly or in combination, in myelinating and nonmyelinating Schwann cells (NMSCs) of transgenic mice. The double mutant mice displayed significant loss of thermal sensitivity accompanied by marked neuropathy of unmyelinated nociceptive sensory axons terminating in the dorsal horn of spinal cords, the primary site for integrating pain and temperature inputs. Neuropathy, although to a lesser extent, was also observed in the nociceptive C-fibers in the Remak bundles of sciatic nerves; however, there was no loss of NMSCs that ensheathe these axons. Furthermore, axons wrapped by myelinating Schwann cells and associated myelin sheaths appeared to be unaffected. Relative to the double mutants, axonal neuropathy developed much later in the Fgfr 1 but not Fgfr2 single mutant, indicating a difference in signaling potential of the two receptors, with Fgfr 1 being more robust than Fgfr2. These findings emphasize the importance of Fgfr 1 and Fgfr2 signaling as potential mediators of axon-glial interaction in the peripheral sensory pain pathway primarily via influencing NMSC function, which in turn modulates the structure and function of unmyelinated sensory axons. This study provides a novel molecular mechanism for nociception with possible implications for pain sensitivity in peripheral sensory neuropathies.
\end{abstract}

Key words: FGF; FGF receptors; axonal neuropathy; receptor; glia; Schwann cell

\section{Introduction}

Schwann cell-axon interactions are critical for the normal development and functioning of peripheral nerves (Nave and Trapp, 2008). Myelinating Schwann cells wrap multilamellar membranes around large-diameter axons to form myelin, while nonmyelinating Schwann cells (NMSCs) form Remak bundles that ensheathe several small diameter unmyelinated sensory axons (C-fibers). These C-fibers are primarily responsible for nociception, the sensory detection of noxious stimulus, including thermal stimuli (Shir and Seltzer, 1090). Several molecules, such as Neuregulin 1 (Chen et al., 2003; Michailov et al., 2004), L1 (Haney et al., 1999), integrins (Feltri et al., 2002), MAG (myelinassociated glycoprotein) (Yin et al., 1998), and Po (Li et al., 2006), have been implicated in mediating interactions between peripheral axons and Schwann cells. However, the molecular mecha-

Received Nov. 24, 2008; revised Jan. 2, 2009; accepted Jan. 5, 2009.

This work was supported by National Institutes of Health (NIH) Grant NS38878 (R.B.) and National Multiple Sclerosis Society Grant RG 4087-A-3 (R.B.). We thank Dr. D. M. Ornitz (Washington University School of Medicine, St Louis, M0) for providing us with floxed Fgfr1 and Fgfr2 transgenic mice, Dr. K. Nave (Max Planck Institute of Experimental Medicine, Goettingen, Germany) for CNP-Cre mice, Dr. M. N. Rasband (Baylor College of Medicine, Houston, TX) for review of this manuscript, and Drs. S. Patel (VA Connecticut Healthcare System) and N. K. Dwyer (Lipid Cell Biology, NIH) for their comments on the electron micrograph of axonal spheroids.

Correspondence should be addressed to Dr. Rashmi Bansal, Department of Neuroscience, University of Connecticut Medical School, Farmington, CT 06030-3401. E-mail: bansal@neuron.uchc.edu.

D0I:10.1523/JNEUROSCI.5615-08.2009

Copyright $\odot 2009$ Society for Neuroscience $\quad 0270-6474 / 09 / 291608-07 \$ 15.00 / 0$ nisms underlying Schwann cell-axon interactions and the involvement of other signaling molecules in this process remain to be further elucidated.

Fibroblast growth factor-2 (FGF2) is a key regulator of peripheral nerve regeneration following injury (for review, see Grothe and Nikkhah, 2001). FGF2 and three of its receptors, Fgfr1, Fgfr2, and Fgfr3, are expressed by Schwann cells and dorsal root ganglion (DRG) neurons and are upregulated following injury (Grothe and Nikkhah, 2001). FGF2 is a known mitogen for Schwann cells in culture (Davis and Stroobant, 1990), and its important role during regeneration of myelinated peripheral nerves has been well documented in FGF2-null and Fgfr3-null mice (Grothe et al., 2006). However, the role and mechanisms of FGF signaling via Fgfr 1 and Fgfr2, particularly in NMSCs for maintaining normal peripheral nerve structure and function, is poorly understood. Therefore, to elucidate the in vivo role of FGF signaling in the PNS, we generated conditional knock-out mice with disrupted Fgfr1 and Fgfr2 signaling in both myelinating Schwann cells and NMSCs.

We found that a lack of Fgfr 1 and Fgfr2 signaling in NMSCs in the double mutant and to a lesser extent in the Fgfr 1 single mutant resulted in neuropathy of unmyelinated C-fiber sensory axons and was accompanied by functional impairment of thermal sensitivity without loss of NMSCs. These findings emphasize the importance of FGF signaling for normal functioning of NMSCs 
A
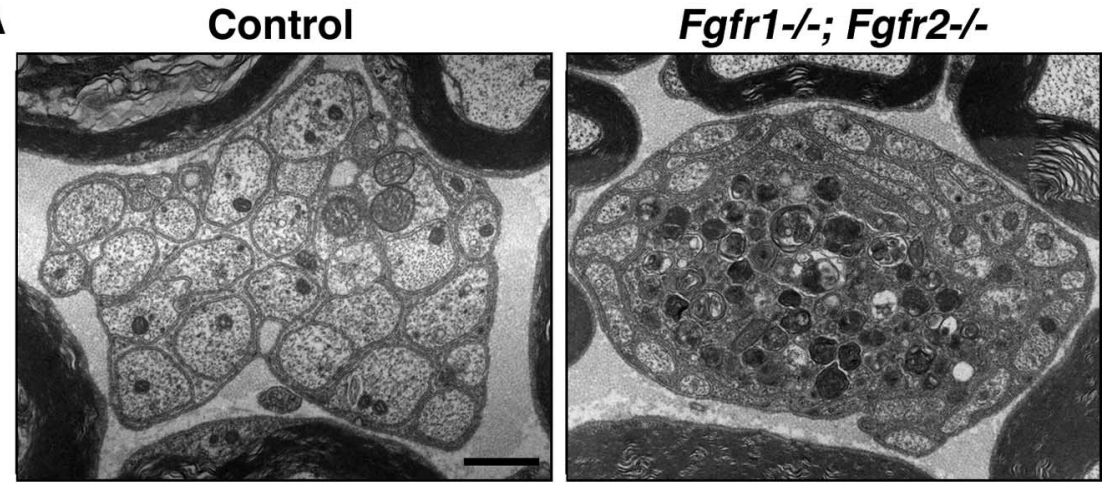

B
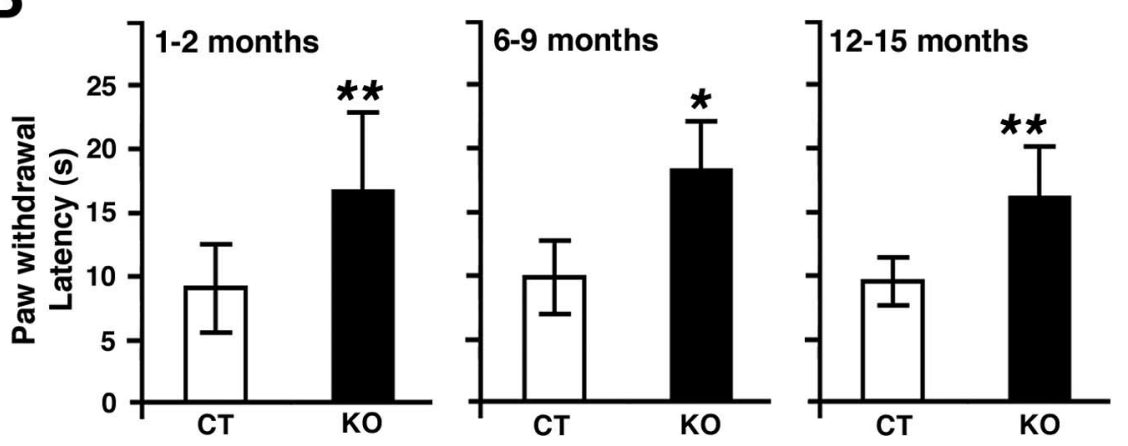

Figure 1. Fgfr ${ }^{-1-} ; \mathrm{Fgfr}^{-1-}$ mice show neuropathy of unmyelinated sensory axon in sciatic nerve and have impaired responses to noxious thermal stimuli. $\boldsymbol{A}$, Electron microscopy analysis of sciatic nerve from 10 -month-old control and Fgfr $1^{-/-}$; $\mathrm{Fgfr}^{-1-}$ littermates show abnormal electron dense structures in some axons of the Remak bundles of the mutant mice. Scale bar, $1 \mu \mathrm{m}$. B. Paw withdrawal latency in seconds was examined by hot plate test at $55^{\circ} \mathrm{C}$ in a total of 27 control (CT) and 27 mutant (KO) mice (divided into 3 age groups of 1-2,6-9, and 12-15 months). Note that the increased latency time is indicative of reduced heat sensitivity of the mutant mice. ${ }^{*} p<0.01,{ }^{* *} p<0.05$ analyzed by Mann-Whitney $U$ test. Error bars, SEM. $n=12$ (T, $10 \mathrm{KO}$ (1-2 months), 7 CT, 6 KO (6 -9 months), 8CT, $11 \mathrm{KO}$ (12-15 months). Out of 27, $19 \mathrm{KO}$ s were littermates with controls.

in maintaining the integrity and pain sensitivity of the sensory axons.

\section{Materials and Methods}

Generation of Fgfr1 and Fgfr2 single and Fgfr1/Fgfr2 double conditional knock-out mice

The generation of floxed Fgfr $1^{f l o x /+}$ and $F g f r 2^{f l o x /+}$ (129SV/CD1 strains) and $\mathrm{CNP}^{\text {cre/+ }}$ mice $\left(2^{\prime}, 3^{\prime}\right.$-cyclic nucleotide $3^{\prime}$-phosphohydrolase; C57BL/6 strain) has been previously described (Pirvola et al., 2002; Lappe-Siefke et al., 2003; Kaga et al., 2006). Briefly, loxP sites in the Fgfr $\mathrm{f}^{\text {flox/+ }}$ mice flank regions encoding the transmembrane and tyrosine kinase domains and in the Fgfr flox/+ mice flank the ligand-binding IgIII domain and the transmembrane domain of the receptors. Deletion of these regions renders these receptors inactive (Pirvola et al., 2002; Kaga et al., 2006).

As described previously (Kaga et al., 2006), to generate single or double conditional knock-out mice, Fgfr $1^{\text {flox/+ }}$, Fgfr flox/+ $^{\text {, }}$ or Fgfr $1^{\text {flox/flox; }}$; $\mathrm{Fgfr} 2^{\text {flox/flox }}$ transgenic mice were suitably crossed with $\mathrm{CNP}^{\text {cre/+ }}$ mice to produce progeny in which Fgfr1 and/or Fgfr2 are disrupted in CNPexpressing myelinating and nonmyelinating Schwann cells and oligodendrocytes.

The efficiency and specificity of Fgfr1 and Fgfr2 recombination was assessed by PCR, immunoblotting, and in situ hybridization (supplemental Fig. 1, available at www.jneurosci.org as supplemental material) (Kaga et al., 2006). CNP ${ }^{\mathrm{Cre} /+}$ mice were also mated with reporter mice, Rosa26-YFP (yellow fluorescent protein), for assessment of Cremediated recombination in the sciatic nerve and spinal cord (supplemental Fig. 1, available at www.jneurosci.org as supplemental material).

\section{Behavior tests}

Hot plate test. The hot plate test was performed as described (Crawley, 2007) using analgesia meter (myNeuroLab) maintained at 52 or $55 \pm$ $0.2^{\circ} \mathrm{C}$. Mice of three age groups $(1-2,6-9$, $12-15$ months) were placed on the hot plate and the time taken to begin licking their hindpaws, shaking, or jumping (latency) was recorded. To minimize damage to the tissue a cutoff times of 60 or $30 \mathrm{~s}$ were set. Test was performed blindly with respect to the genotypes of the mice by three investigators.

von Frey test. Mechanical sensitivity of mice was evaluated by this test as described previously (Chen et al., 2003; Crawley, 2007) (supplemental Fig. 3, available at www.jneurosci.org as supplemental material).

Motor function tests. Rotarod and hangingwire tests were performed as described previously (Crawley, 2007) (supplemental Fig. 3, available at www.jneurosci.org as supplemental material).

\section{Histology and immunohistochemistry}

Mice were perfused with $4 \%$ paraformaldehyde/PBS. Sciatic nerves, sural nerves, DRGs, and spinal cords were cryoprotected and embedded, and cryostat cross sections $(15 \mu \mathrm{m})$ were prepared. Sections were incubated overnight $\left(4^{\circ} \mathrm{C}\right)$ in anti-calcitonin-gene-relatedprotein (CGRP; 1:200; Bachem), anti-p75 (1: 200 ; Promega), anti- $\beta$-amyloid precursor protein ( $\beta$-APP; $1: 500$; Zymed Laboratories) or biotinylated Griffonia simplicifolia lectin-I isolectin-B4 (IB4; 1:100; Vector Laboratories). For $\beta$-APP, sections were pretreated with $0.1 \%$ $\mathrm{H}_{2} \mathrm{O}_{2}$ and heated $(5 \mathrm{~min}, 0.1 \mathrm{M}$ citrate buffer, $\mathrm{pH} 6)$. Sections were incubated ( $1 \mathrm{~h})$ with secondary antibodies conjugated to Alexa 488 or 594 (1:500; Invitrogen) or Cy3 (1:600, Jackson ImmunoResearch Laboratories) or with avidin-biotin peroxidase (ABC-Kit; Vector Laboratories). Nuclei were counterstained with Hoechst 33342. For FluoroJade B labeling, the sections were dehydrated, rehydrated, treated with $0.06 \%$ potassium permanganate $(10 \mathrm{~min}$ ), and incubated in $0.0004 \%$ Fluoro-Jade B solution in $0.1 \%$ acetic acid $(20 \mathrm{~min})$.

\section{Electron microscopy}

Electron microscopy on spinal cords and sciatic nerves was performed as described (Marcus et al., 2006). Sections ( $1 \mu \mathrm{m}$ ) were stained with toluidine blue for light microscopy.

In situ hybridization, immunoblotting, and PCR

These procedures were performed as described previously (Kaga et al., 2006) (supplemental Figs. 1, 2, available at www.jneurosci.org as supplemental material).

\section{Results}

Floxed Fgfr1 and Fgfr2 transgenic mice were crossed with $\mathrm{CNP}^{\text {cre/+ }}$ mice to produce progeny with single or double Fgfr null mutations in CNP-expressing cells. In the peripheral nervous system, CNP is expressed by myelinating Schwann cells and NMSCs, but not by neurons (Toma et al., 2007). CNP-Cremediated recombination was specifically achieved in the Fgfr mutant mice (supplemental Fig. 1, available at www.jneurosci. org as supplemental material) (see Materials and Methods).

The ultrastructure of $F g f r 1^{-/-} ; F g f r 2^{-/-}$sciatic nerves was analyzed by electron microscopy and semithin sections. We found that the loss of these receptors did not adversely affect the structure or numbers of myelinated axons and that the myelin appeared to be well compacted, with no reduction in thickness or in P0 protein expression (supplemental Fig. 2, available at www. 
jneurosci.org as supplemental material). In contrast, some sensory axons in the Remak bundles of $F g f r 1^{-/-} ; F g f r 2^{-/-}$sciatic nerves contained electron-dense structures (Fig. $1 A$ ) suggestive of axonal degeneration (Yamano et al., 1982). Such structures were never found in littermate controls. Since a few Remak bundles in Fgfr1 ${ }^{-1-} ; F_{g f r} 2^{-1-}$ sciatic nerves clearly had degenerating axons, we asked whether a widespread defect in sensory axon integrity was more apparent by measuring nociception in Fgfr1 ${ }^{-/-} ; \mathrm{Fgfr} 2^{-/-}$mice. We therefore performed the "hot plate" test to examine the response of thermal nociception conveyed primarily by unmyelinated C-fibers found in Remak bundles (Fig. 1B). Fgfr1 ${ }^{-/-} ; F_{g f r} 2^{-/-}$mice, tested using three different age groups (1-2, 6-9, 12-15 months), exhibited significantly longer $(\sim 1.6$-fold $)$ paw withdrawal latencies than littermate control mice at $55^{\circ} \mathrm{C}$. The same test, performed at $52.5^{\circ} \mathrm{C}$, yielded similar results (data not shown). These findings suggest that $\mathrm{FgFr}^{-/-}$; $\mathrm{Fgfr} 2^{-/-}$mice have significantly impaired thermosensory functions in unmyelinated axons.

We also performed the von Frey, rotarod, and hanging-wire tests using these mice to evaluate their mechanosensory and motor functions, which are driven primarily by myelinated axons (Shir and Seltzer, 1990). No impairment of these functions was observed, consistent with the normal structure of peripheral myelinated axons in these mutants (supplemental Figs. 2, 3, available at www.jneurosci.org as supplemental material).

How do such profound physiological changes occur in the absence of dramatic axonal loss in the Remak bundles? Since lamina I and II of the dorsal horn of the spinal cord (Fig. $2 \mathrm{Aa}$ ) is the predominant site that receives the unmyelinated nociceptive C-fiber afferents and is a primary site for integrating pain and temperature sensation information, one explanation might be that there are disrupted connections in this region (Hunt and Mantyh, 2001). Toluidine blue staining of $\mathrm{Fg}_{\mathrm{fr}} \mathrm{1}^{-/-}$; Fgfr2 $2^{-/-}$spinal cords revealed numerous large round structures (spheroids) restricted to the lamina I and II of the dorsal horn (Fig. $2 B a, B b$ ). These abnormalities were seen in both the cervical and lumbar regions of $\mathrm{Fgfr}^{-/-} ; \mathrm{Fg} f 2^{-/-}$ mice spinal cords. Electron microscopy analysis (Fig. $2 A b-A d$ ) revealed large $(10-20 \mu \mathrm{m})$ axonal spheroids that correspond to the dense spheroids seen in the toluidine blue stained semithin sections (Fig. $2 B$ ). These spheroids are membrane-bound structures containing large collections of dense bodies and vesicles with membrane whorls and amorphous substances of varying densities. These materials selectively accumulated in the spheroids but not in the cytoplasm of neighboring cells. The spheroi-
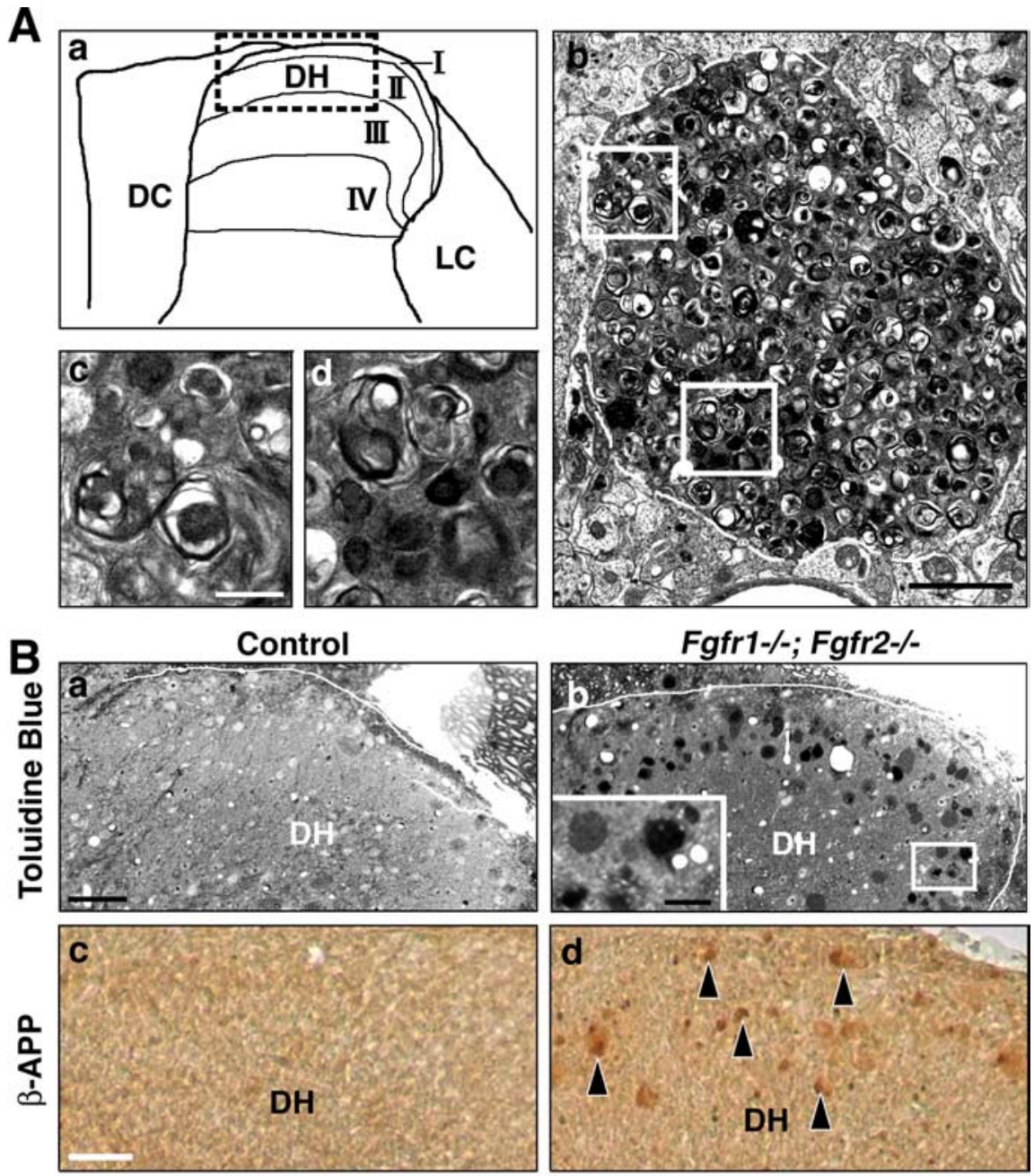

2. $\mathrm{Fgfr}^{-1-} ; \mathrm{Fgfr}^{-1-}$ mice show degeneration of unmyelinated sensory axons in spinal cord dorsal horn lamina l and II. $\boldsymbol{A a}$, Diagram of laminae I-IV of dorsal horn (DH); boxed area is shown in other panels. $\boldsymbol{A} \boldsymbol{b}$, Electron micrograph of dorsal horn from 10 months $\mathrm{Fgfr}^{-1-} ; \mathrm{Fgfr}^{-1-}$ mice shows a neuropathic axonal spheroid. Ac, Ad, Higher magnifications of boxed areas shows electron dense structures within the spheroid. $\boldsymbol{B}$, Toluidine-blue-stained large axonal spheroids are absent from control $(\boldsymbol{B a})$ but present in lamina I/ll of $\mathrm{Fgfr}^{-/-} ; \mathrm{Fgfr}^{-/-}$littermates $(\boldsymbol{B} \boldsymbol{b})$. Spinal cord sections from 8-month-old control $(\boldsymbol{B C}, \boldsymbol{B e})$ and $\mathrm{Fgfr}^{-1-} ; \mathrm{Fgfr} 2^{-1-}$ littermates (Bd, Bf) stained for $\beta$-amyloid precursor protein $(\beta$-APP) and Fluoro-Jade B showed degenerated axons (examples shown by arrowheads). Three controls and mutants were examined for each analysis. Representative images are shown. Scale bars: $\boldsymbol{A} \boldsymbol{b}, 2 \mu \mathrm{m} ; \boldsymbol{A c}, \boldsymbol{A d}, 0.5 \mu \mathrm{m} ; \boldsymbol{B} \boldsymbol{a}, \boldsymbol{B} \boldsymbol{b}, 100 \mu \mathrm{m} ; \boldsymbol{B} \boldsymbol{b}$ inset, $25 \mu \mathrm{m} ; \boldsymbol{B} \boldsymbol{C}-\boldsymbol{B} \boldsymbol{f}, 50 \mu \mathrm{m}$. DH, Dorsal horn; DC, dorsal column; LC, lateral column. dal structures were never observed in control littermate mice, even at 14 months of age. Immunostaining with anti- $\beta$-amyloid precursor protein ( $\beta$-APP) and Fluoro-Jade B, two common markers of degenerating axons (Coleman, 2005; Schmued et al., 1997) (Fig. $2 B c-B f$ ) showed labeling of spheroids by these markers in lamina I and II of $F g f r 1^{-/-} ; F g f r 2^{-/-}$dorsal horns, but not in control mice. Thus, the spheroids of mutant spinal cords are degenerating nociceptive C-fiber axons, and their disruption is consistent with impaired nociceptive signaling.

C-fibers are divided into two mostly nonoverlapping groups: (1) IB4-lectin-binding fibers that express receptors for glial-cell- 

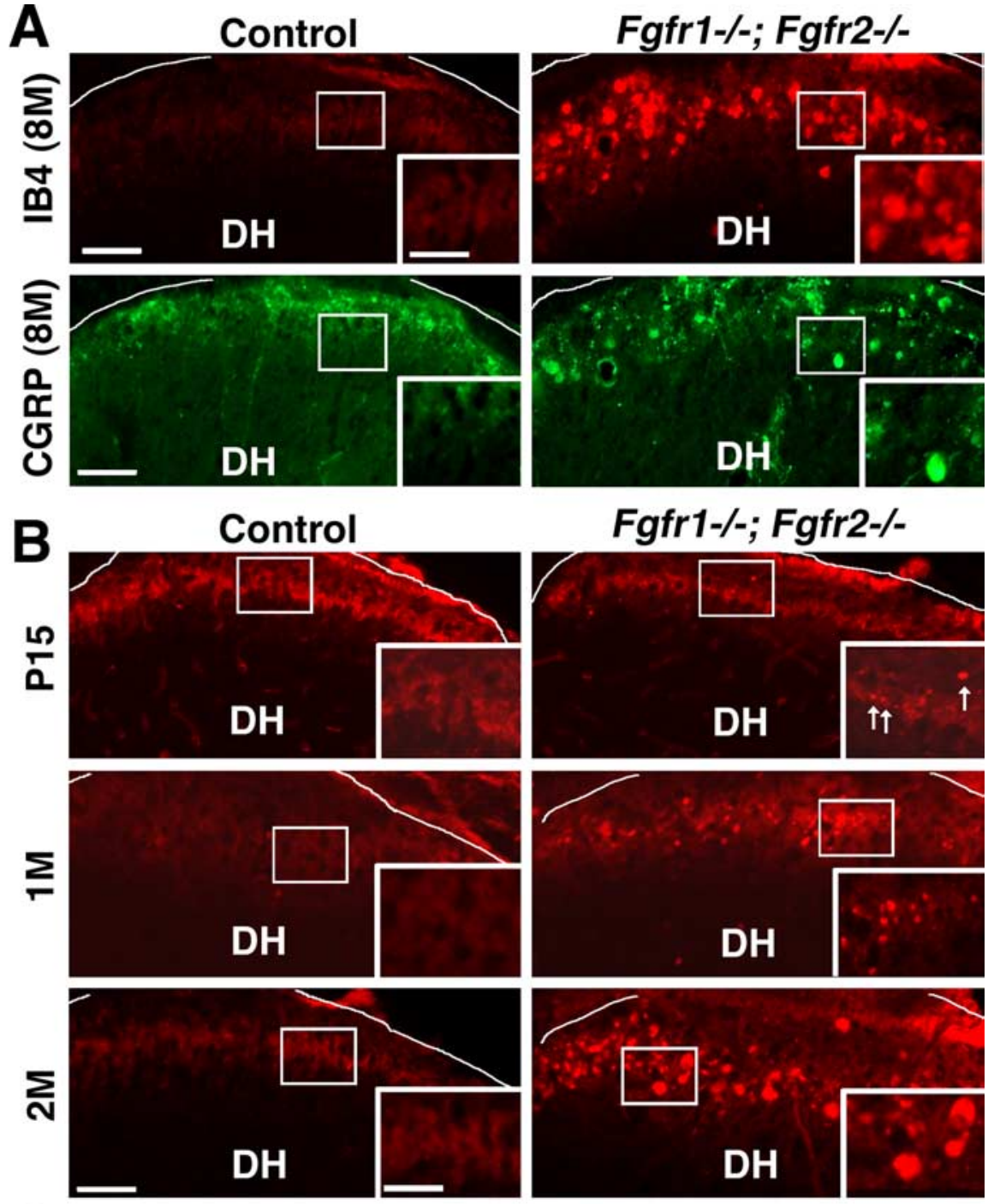

B

Fgfr1-/-; Fgfr2-/-
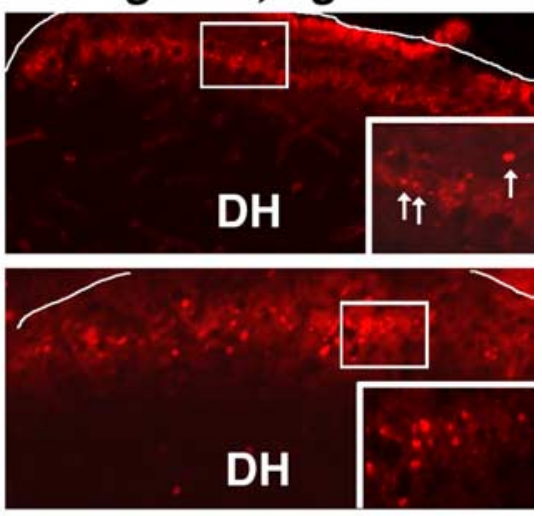

Q

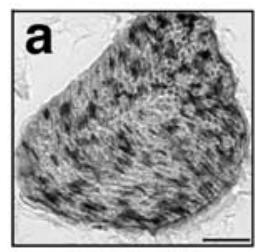

Control

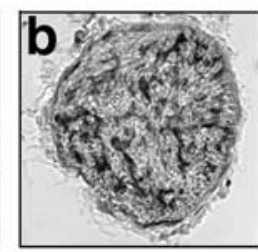

Fgfr1-/-;Fgfr2-/-

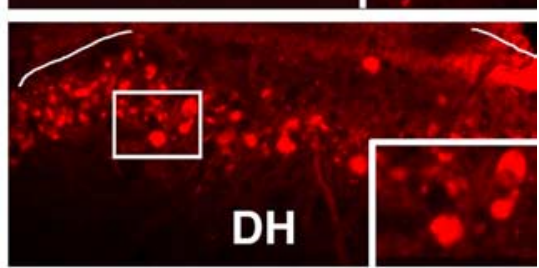

\begin{tabular}{|c|c|}
\hline & $\begin{array}{c}\text { Number of } \mathrm{p75} \\
\text { cells } / \mathrm{mm}^{2}\end{array}$ \\
\hline Control & $419.3 \pm 15.0$ \\
\hline $\begin{array}{c}\text { Fgfr1-/-; } \\
\text { Fgfr2-- }\end{array}$ & $411.1 \pm 64.0$ \\
\hline
\end{tabular}

Figure 3. Degeneration of both IB4 + and CGRP + subgroups of unmyelinated sensory axon in Fgfr ${ }^{-/-} ; \mathrm{Fgfr}^{-/-}$mice without loss of nonmyelinating Schwann cells. $A$, Spinal cord cross sections show IB4 + and CGRP + spheroids in lamina I/II of dorsal horn (DH) in Fgfr ${ }^{-/-}$;Fgfr ${ }^{-/-}$but not in littermate controls at 8 months (M). B , IB4 staining of postnatal day 15 (P15), $1 \mathrm{M}$, and $2 \mathrm{M}$ spinal cords shows onset of spheroid formation at $\mathrm{P} 15$, which progressively increase in size and numbers reaching a plateau around 2M. Boxed areas magnified in insets. Three controls and mutants were examined for each analysis. Representative images are shown. $\boldsymbol{C}$, Cross sections of sural nerve from $2 \mathrm{M}$ control $(\boldsymbol{C a})$ and $F g f r 1^{-/-} ; \mathrm{Fgfr} 2^{-/-}$littermates $(\boldsymbol{C b})$ stained with anti-p75 show equal numbers of p75 + NMSCs $(\boldsymbol{C}) . n=3$. Scale bars: $\boldsymbol{A}, \boldsymbol{B}, 100 \mu \mathrm{m} ; \boldsymbol{C}, 50 \mu \mathrm{m}$; insets, $50 \mu \mathrm{m}$.

derived neurotrophic factor (GDNF) terminating almost exclusively within the inner lamina II; and (2) fibers containing calcitonin-gene-related peptide (CGRP), substance $\mathrm{P}$, and TrkA receptor, terminating primarily in lamina I and outer lamina II (Hunt and Mantyh, 2001). Although both C-fiber types are nociceptive and respond to similar stimuli, their differential axonal receptor expression profiles suggest that their response to growth factors may also differ. Therefore, we labeled spinal cord sections for IB4 and CGRP to confirm that the spheroids correspond to nociceptive $\mathrm{C}$-fibers and to determine their subtype (Fig. 3A). The large spheroidal structures were found to be strongly labeled by IB4 (in lamina II) and CGRP (in lamina I/II) in $\mathrm{Fgfr}^{-/-} ; \mathrm{Fgfr} 2^{-/-}$mice. These structures were not colabeled with the Hoechst nuclear stain, confirming that these were axonal structures and not cell bodies. These data strongly suggest that both subgroups of sensory C-fibers in Fgfr1 ${ }^{-/-} ; F_{g f r}{ }^{-/-}$mice undergo neuropathological changes.

Is the observed C-fiber neuropathology a consequence of disrupted signaling during development or a loss of signals required for maintenance of axonal integrity? To answer this question we analyzed spinal cords from control and $\mathrm{Fg} f \mathrm{rl}^{-/-}$; $\mathrm{Fg} f \mathrm{2}^{-1-}$ mice as a function of age (Fig. $3 A, B)$. No spheroids (IB4+ or CGRP + ) were observed at P9 (data not shown), and only small spheroids could be occasionally observed at P15 in the mutants. Their size and number, however, increased progressively with age becoming quite prominent by one-two months (Fig. $3 A, B$ ). A similar conclusion was obtained by analyzing $\beta$-APP and semithin sections (data not shown). Why does elimination of Fgfrl/ Fgfr2 in NMSCs cause C-fiber axonal neuropathy? Loss of FGF signaling in the NMSCs might adversely affect their viability, resulting in axon degeneration similar to mice with disrupted NRG1-ErbB signaling (Chen et al., 2003). To investigate this possibility, we immunostained sciatic nerves and $\mathrm{C}$-fiber rich sural nerve sections with anti-p75, a marker of NMSCs, and counted the total number of positive cells (Fig. 3C). No differences were found between control and $\mathrm{Fgfr} 1^{-/-} ; \mathrm{Fgfr} 2^{-/-}$ mice, suggesting sensory axon degeneration is not due to a loss of NMSCs.

Is the axonal degeneration in the Fgfr1 ${ }^{-1-} ; F g f r 2^{-1-}$ double mutant due to a loss of signaling via Fgfrl or Fgfr2 or both? To address this question we analyzed Fgfr1 ${ }^{-/-}$and $\mathrm{Fgfr} 2^{-/-}$single mutants as a function of age. Examination of the dorsal horn by immunolabeling for IB4, CGRP, and $\beta$-APP or by toluidine blue stained semithin section and EM showed that in contrast to double mutants there was no axonal degeneration in either of the single mutants up to 7 months. By 8 months, however, Fgfr1 ${ }^{-/-}$but not $\mathrm{Fgfr} 2^{-/-}$mice developed numerous axonal spheroids in lamina I/II (Fig. 4; supplemental Fig. 4, available at www.jneurosci.org as supplemental material), suggesting involvement of both receptors, with Fgfr1 playing a more prominent role than Fgfr2.

\section{Discussion}

Pathology of myelinated axons is a common feature in several hereditary peripheral neuropathies in which myelinating 

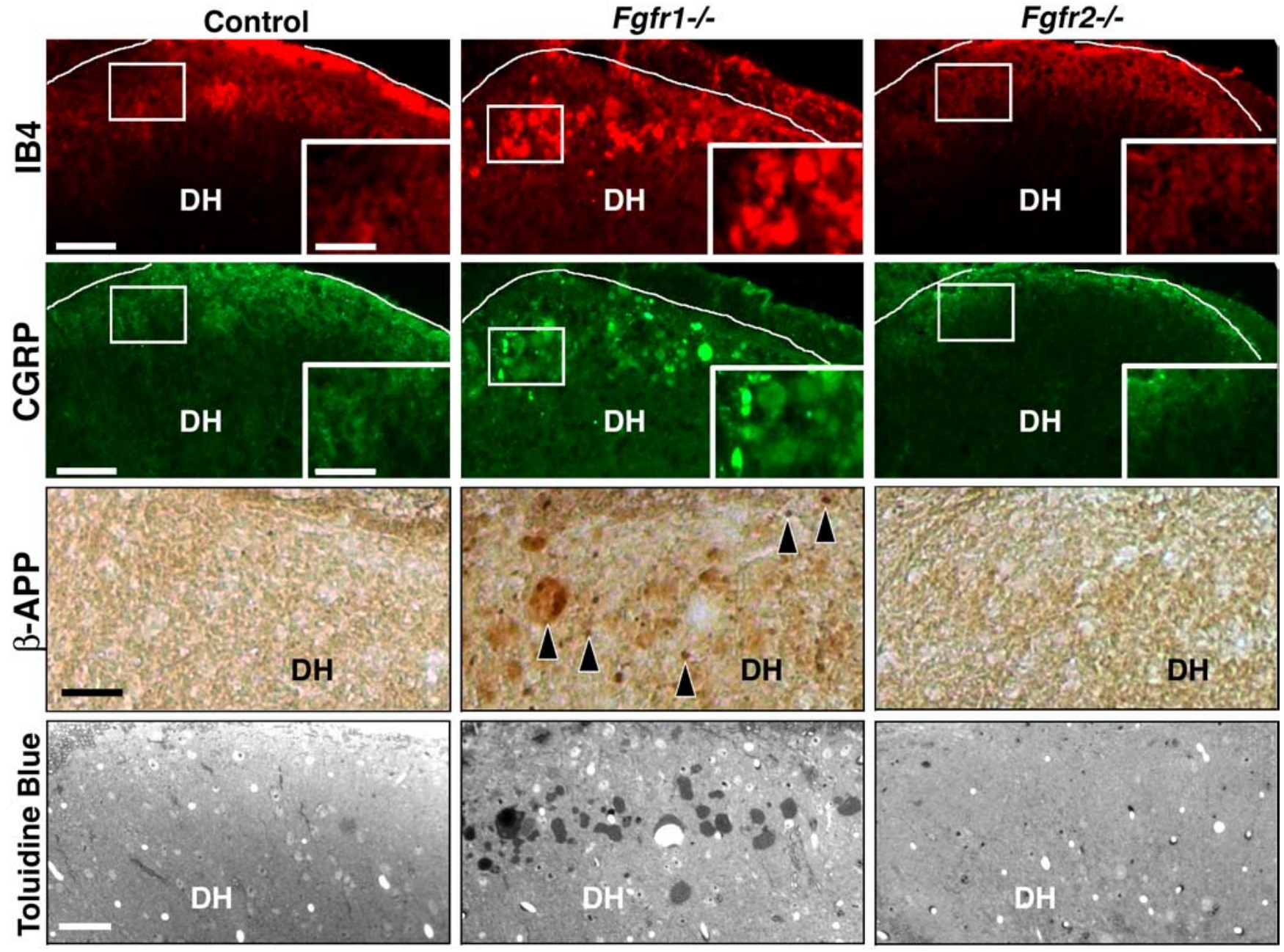

Figure 4. Unmyelinated sensory axon degenerate in $\mathrm{Fgfr}^{-1-}$ but not in $\mathrm{Fgfr}^{-/-}$mice. Spinal cord cross sections showing dorsal horn (DH) of control and Fgfr $1^{-1-}$ or Fgfr2 ${ }^{-/-}$mice stained for IB4, CGRP, or $\beta$-APP at 8 months (M) (boxed areas magnified in insets) and with toluidine blue (semithin sections) at 10M. No spheroids were seen in either of the single mutants until 7M (supplemental Fig. 4, available at www.jneurosci.org as supplemental material). By 8M, they appeared in the Fgfr $1^{-/}$but never in Fgfr2 ${ }^{-/}$mice. Three controls and mutants were examined for each analysis. Representative images are shown. Scale bars: IB4 and CGRP, $100 \mu \mathrm{m} ; \beta$-APP, toluidine blue, and inset, $50 \mu \mathrm{m}$.

Schwann cells bear the primary mutation, suggesting an important modulatory influence of myelinating Schwann cells on axons (Sahenk, 1999; Wrabetz et al., 2004; Nave and Trapp, 2008). Here, we report that disruption of Fgfr1 and Fgfr2 signaling in nonmyelinating Schwann cells (NMSCs) resulted in neuropathy of nonmyelinated peripheral sensory axons, accompanied by significant insensitivity to noxious thermal stimuli. In contrast, no abnormalities were observed in the structure or functions of myelinated axons from disrupted Fgfr signaling.

The large spheroidal structures observed in lamina I and II of the spinal cord dorsal horn in the $\mathrm{Fgfr}^{-/-} ; \mathrm{Fgfr}^{-/-}$mice may represent degenerating presynaptic axonal terminal or distal region of C-fiber sensory axons. Similar spheroids, reminiscent of proliferative lysosomal structures have been observed in various lysosomal storage disorders (Fujisawa, 1988), including Niemann-Pick type C disease, where they were observed in the dorsal horn and described as "dystrophic presynaptic axonal terminals" (Ohara et al., 2004). Similar structures were also reported in Alzheimer disease (Nixon, 2007). It should be noted that although dramatic neuropathy of axonal terminals was observed in the dorsal horn of Fgfr mutant mice, no loss of neuronal cell bodies was seen in the DRG by electron microscopy (data not shown). This raises the possibility that spheroid formation may represent a form of distal axonopathy in which the terminal portion of axons and presynaptic axon terminals are preferentially affected. It has been shown that axons degenerate earlier than the cell body in Niemann-Pick type C mouse brain (Ohara et al., 2004) and after transaction of the sciatic nerve (Tandrup et al., 2000). Furthermore, in certain conditions, neuronal cell bodies remain viable even while the axons are degenerating (Sagot et al., 1995), dissociating neuronal and axonal functions. Axonal spheroids in the rat gracile nuclei can also develop as a consequence of normal aging (Fujisawa, 1988). However in the $\mathrm{FgfrI}^{-/}$; $\mathrm{Fg} f \mathrm{r}^{-/-}$mutants these structures first appear in young adults, suggesting that this defect differs from that seen in normal aging animals. C-fiber-evoked activity in the dorsal horn begins to develop gradually only over the postnatal period into adulthood (Fitzgerald, 2005); similarly, the manifestation of the C-fiber defect in our mutant mice also developed over approximately a parallel time frame. Therefore, it is possible that the defect may be somehow correlated with the functional maturity of the C-fibers.

Although Schwann cells and DRG neurons both express Fgfr 1 and Fgfr2 (Grothe and Nikkhah, 2001), these receptors should be eliminated in principle only from CNP-expressing Schwann cells of Fgfr1 and Fgfr 2 conditional knock-out mice. Nevertheless, the possibility exists that Fgfrs may have also been eliminated from 
DRG neurons as a result of a Cre-mediated recombination that occurred earlier in embryonic development if CNP promoter activity were present in neural precursors. Furthermore, dysfunction of sensory neurons can potentially occur due to deletion of Fgfrs from the peripheral (skin) or central (spinal cord neurons) targets of unmyelinated axons, resulting in impairment of trophic support from these targets. In situ hybridization analysis of the mutant mice, using a probe against the deleted sequence of Fgfrl, failed to demonstrate loss of Fgfrl from either DRG and spinal cord neurons or from regions of the skin that are innervated by $\mathrm{C}$-fibers, thus ruling out these possibilities (supplemental Fig. 1, available at www.jneurosci.org as supplemental material). We therefore favor the model in which the neuropathy of sensory neurons in mutant mice is caused by the elimination of Fgfrl and Fgfr2 in NMSCs, which then indirectly modulate neuronal function, leading to neuropathy.

The phenotypic difference that was observed between Fgfrl and Fgfr 2 single mutants suggests that these Fgfrs have distinct signaling potentials, thresholds, or specificities in NMSCs, as has been observed in oligodendrocytes (Fortin et al., 2005). Although Fgfrl signaling is more robust than Fgfr2, the phenotype of $\mathrm{Fgfr}^{-/-}$; Fgfr2 ${ }^{-/-}$double mutants is more severe than the Fgfr1 $1^{-/-}$single mutant, suggesting that Fgfr2 is involved as well. Thus, the phenotype of the double mutant potentially emerges from cooperative signaling by both receptors.

Degeneration and loss of sensory axons resulting from loss of NMSCs bearing the ErbB receptor mutation has been reported (Chen et al., 2003); however, unlike the ErbB mutant, the axonal degeneration in the $\mathrm{FgfrI}^{-/-} ; \mathrm{Fg} f \mathrm{r}^{-/-}$mice was not coupled to the death of NMSCs. Therefore NMSC mortality may not be necessary, and simply perturbing NMSC receptor function may be sufficient to adversely modulate axonal function. Nevertheless, in both cases it is clear that disruption of axon-glia signaling resulted in neuropathology.

Exactly how Fgfr1/2 signaling in NMSCs influences axonal function remains to be determined. A model can be proposed in which Fgfr signaling in NMSCs regulates the production or delivery of certain trophic factors or regulates the expression of cell surface ligands that are essential for normal function or survival of axons, the disruption of which in the mutant would then result in axonal neuropathy and degeneration. For example, FGF signaling is known to upregulate GDNF and NGF mRNA in cells expressing Fgfr1 and Fgfr2 (Suter-Crazzolara and Unsicker, 1996; Ferhat et al., 1997). These growth factors, produced by Schwann cells (Bandtlow et al., 1987; Hammarberg et al., 1996), provide essential trophic support to sensory neurons expressing receptors of these growth factors (Chen et al., 2003). Disruption of Fgfr 1/2 signaling in nonmyelinating Schwann cells may also affect the expression of modulatory molecules (such as MAG for myelinating Schwann cells) (Yin et al., 1998) that function as ligands to help stabilize the axonal cytoskeleton and transport. Impairment of axonal transport may in turn lead to the accumulation of molecules, organelles, and disorganized cytoskeletal elements in local enlargements of distal axons or axon terminals, thereby giving rise to spheroidal structures. The accumulation of $\beta$-APP in these spheroids, as seen in the mutants, is consistent with a failure in efficient axonal transport, which is considered as an early event in the process of axonal degeneration (Coleman, 2005).

In summary, the selective loss of Fgfr $1 / 2$ signaling in NMSCs results in marked neuropathy of sensory C-fibers accompanied by significant insensitivity to thermal stimuli. We propose that neuron-derived FGFs activate glial Fgfrs, which then transduce signals for production of trophic factors or adhesion molecules that are essential for maintenance of sensory functions like axonal transport or survival. Dysfunction of NMSC and Fgfr signaling may therefore be implicated in the modulation of pain sensitivity in peripheral sensory neuropathies.

\section{References}

Bandtlow CE, Heumann R, Schwab ME, Thoenen H (1987) Cellular localization of nerve growth factor synthesis by in situ hybridization. EMBO J 6:891-899.

Chen S, Rio C, Ji RR, Dikkes P, Coggeshall RE, Woolf CJ, Corfas G (2003) Disruption of ErbB receptor signaling in adult non-myelinating Schwann cells causes progressive sensory loss. Nat Neurosci 6:1186-1193.

Coleman M (2005) Axon degeneration mechanisms; commonality amid diversity. Nat Rev Neurosci 6:889-898.

Crawley JN (2007) What's wrong with my mouse? Behavioral phenotype of transgenic and knockout mice, pp 62-109. New York: Wiley.

Davis JB, Stroobant P (1990) Platelet-derived growth factors and fibroblast growth factors are mitogens for rat Schwann cells. J Cell Biol 110:1353-1360.

Feltri ML, Graus Porta D, Previtali SC, Nodari A, Migliavacca B, Cassetti A, Littlewood-Evans A, Reichardt LF, Messing A, Quattrini A, Mueller U, Wrabetz L (2002) Conditional disruption of beta 1 integrin in Schwann cells impedes interactions with axons. J Cell Biol 156:199-209.

Ferhat L, Represa A, Zouaoui-Aggoun D, Ferhat W, Ben-Ari Y, Khrestchatisky M (1997) FGF-2 induces nerve growth factor expression in cultured rat hippocampal neurons. Eur J Neurosci 9:1282-1289.

Fitzgerald M (2005) The development of nociceptive circuits. Nat Rev Neurosci 6:507-520.

Fortin D, Rom E, Sun H, Yayon A, Bansal R (2005) Distinct fibroblast growth factor (FGF)/FGF receptor signaling pairs initiate diverse cellular responses in the oligodendrocyte lineage. J Neurosci 25:7470-7479.

Fujisawa K (1988) Study of axonal dystrophy. Posterior funiculus and posterior column of ageing and old rats. Acta Neuropathol 76:115-127.

Grothe C, Nikkhah G (2001) The role of basic fibroblast growth factor in peripheral nerve regeneration. Anat Embryol 204:171-177.

Grothe C, Haastert K, Jungnickel J (2006) Physiological function and putative therapeutic impact of the FGF-2 system in peripheral nerve regeneration-lessons from in vivo studies in mice and rats. Brain Res Rev 51:293-299.

Hammarberg H, Piehl F, Cullheim S, Fjell J, Hökfelt T, Fried K (1996) GDNF mRNA in Schwann cells and DRG satellite cells after chronic sciatic nerve injury. Neuroreport 7:857-860.

Haney CA, Sahenk Z, Li C, Lemmon VP, Roder J, Trapp BD (1999) Heterophilic binding of L1 on unmyelinated sensory axons mediates Schwann cell adhesion and is required for axonal survival. J Cell Biol 146:1173-1184.

Hunt SP, Mantyh PW (2001) The molecular dynamics of pain control. Nat Rev Neurosci 2:83-91.

Kaga Y, Shoemaker WJ, Furusho M, Bryant M, Rosenbluth J, Pfeiffer SE, Oh L, Rasband M, Lappe-Siefke C, Yu K, Ornitz DM, Nave KA, Bansal R (2006) Mice with conditional inactivation of fibroblast growth factor receptor-2 signaling in oligodendrocytes have normal myelin but display dramatic hyperactivity when combined with Cnpl inactivation. J Neurosci 26:12339-12350.

Lappe-Siefke C, Goebbels S, Gravel M, Nicksch E, Lee J, Braun PE, Griffiths IR, Nave KA (2003) Disruption of Cnp1 uncouples oligodendroglial functions in axonal support and myelination. Nat Genet 33:366-374.

Li J, Bai Y, Ianakova E, Grandis M, Uchwat F, Trostinskaia A, Krajewski KM, Garbern J, Kupsky WJ, Shy ME (2006) Major myelin protein gene (P0) mutation causes a novel form of axonal degeneration. J Comp Neurol 498:252-265.

Marcus J, Honigbaum S, Shroff S, Honke K, Rosenbluth J, Dupree JL (2006) Sulfatide is essential for the maintenance of CNS myelin and axon structure. Glia 53:372-381.

Michailov GV, Sereda MW, Brinkmann BG, Fischer TM, Haug B, Birchmeier C, Role L, Lai C, Schwab MH, Nave KA (2004) Axonal neuregulin-1 regulates myelin sheath thickness. Science 304:700-703.

Nave KA, Trapp BD (2008) Axon-glial signaling and the glial support of axon function. Annu Rev Neurosci 31:535-561.

Nixon RA (2007) Autophagy, amyloidogenesis and Alzheimer disease. J Cell Sci 120:4081-4091. 
Ohara S, Ukita Y, Ninomiya H, Ohno K (2004) Axonal dystrophy of dorsal root ganglion sensory neurons in a mouse model of Niemann-Pick disease type C. Exp Neurol 187:289-298.

Pirvola U, Ylikoski J, Trokovic R, Hébert JM, McConnell SK, Partanen J (2002) FGFR1 is required for the development of the auditory sensory epithelium. Neuron 35:671-680.

Sagot Y, Dubois-Dauphin M, Tan SA, de Bilbao F, Aebischer P, Martinou JC, Kato AC (1995) Bcl-2 overexpression prevents motoneuron cell body loss but not axonal degeneration in a mouse model of a neurodegenerative disease. J Neurosci 15:7727-7733.

Sahenk Z (1999) Abnormal Schwann cell-axon interaction in CMT neuropathies-the effects of mutant Schwann cells on the axonal cytoskeleton and regeneration-associated myelination. Ann NY Acad Sci 883: 415-426.

Schmued LC, Albertson C, Slikker W Jr (1997) Fluoro-Jade: a novel fluorochrome for the sensitive and reliable histochemical localization of neuronal degeneration. Brain Res 751:37-46.

Shir Y, Seltzer Z (1990) A-fibers mediate mechanical hyperesthesia and al- lodynia and C-fibers mediate thermal hyperalgesia in a new model of causalgiform pain disorders in rats. Neurosci Lett 115:62-67.

Suter-Crazzolara C, Unsicker K (1996) GDNF mRNA levels are induced by FGF-2 in rat C6 glioblastoma cells. Mol Brain Res 41:175-182.

Tandrup T, Woolf CJ, Coggeshall RE (2000) Delayed loss of small dorsal root ganglion cells after transection of the rat sciatic nerve. J Comp Neurol 422:172-180.

Toma JS, McPhail LT, Ramer MS (2007) Differential RIP antigen (CNPase) expression in peripheral ensheathing glia. Brain Res 1137:1-10.

Wrabetz L, Feltri ML, Kleopa KA, Scherer SS (2004) Inherited neuropathies: clinical, genetic, and biological features. In: Myelin biology and disorders (Lazzarini RA, ed), pp 905-951. San Diego: Elsevier Academic.

Yamano T, Shimada M, Okada S, Yutaka T, Kato T, Yabuuchi H (1982) Ultrastructural study of biopsy specimens of rectal mucosa. Its use in neuronal storage diseases. Arch Pathol Lab Med 106:673-677.

Yin X, Crawford TO, Griffin JW, Tu P, Lee VM, Li C, Roder J, Trapp BD (1998) Myelin-associated glycoprotein is a myelin signal that modulates the caliber of myelinated axons. J Neurosci 18:1953-1962. 